\title{
Ordinary Yet Emblematic: The Transnational Correspondence Between an American GI and His Sweetheart during the Korean War
}

\author{
Elizabeth Bruns
}

Aarhus University

\section{ABSTRACT}

Operating on the core premise of microhistory, that the lives of ordinary people are endowed with explanatory power for a specific period or event in history, this article is an analysis of the wartime letters from the $1950 \mathrm{~s}$, written by an American serviceman and his girlfriend, later wife, during the Korean War. The author addresses methodological implications regarding the unique characteristics that personal letters have on their utilization as primary source material in historical and biographical writing. Also included are reflections on the author's close familial relationship to the historical subjects and how this impacts the overall objectivity of the article. An analysis of the letters demonstrates how the couple developed various techniques to mitigate the effects of distance, and how they coped with the pervasive sense of uncertainty and fear that consumed Cold War America. This study broadly contributes to the existing life writing literature by demonstrating how a life writing approach, when applied to a particular moment in history, can be utilized in historical study to tell a previously untold part of that particular moment.

Keywords: letters, microhistory, transnational, marriage 


\section{INTRODUCTION}

Over the course of a two-year period in the early 1950s, an American soldier in Korea and a teacher in Iowa wrote almost daily letters to each other. The bundles of letters, carefully tied up with faded lengths of ribbon, have long been a part of the Eason family lore. The letters are covered in flowing lines of cursive scrawl, and are secure in their aging red-and-blue-striped airmail envelopes. Contained in these bound stacks of unpublished ${ }^{1}$ primary source material are the elements that sustained, and deepened, one American couple's intimate relationship when the conditions of the Korean War separated one from the other.

Wilbur "Curly" Warren Eason (1929-2017) and Helen Alice Caulkins Eason (1928-2016) started writing letters to each other in April 1951 when he was drafted for the Korean War. He was 22 years old, and she was 23. They wrote as he completed his training at various forts around the US, and they continued to write to each other during the eleven months he was overseas in Korea until March of 1953. These two years were a short, but intense and well-documented time in their relationship, as they each wrote a letter virtually every day.

The goal of this project is to illustrate how Helen and Curly, who were separated by the demands of their country, were able to sustain and deepen their relationship through epistolary correspondence. This bottom-up history, a history of two ordinary people, is a significant and important perspective to add to existing literature on the Korean War, and on the possibilities that life writing documents of family members have as sources for scholarly research. The letters were written during a special time in Helen and Curly's lives: he proposed in June of 1951 after they had dated for nearly three years, and they were married on August 1, 1951, while he was on leave from boot camp. The first year and a half of their marriage is captured in these letters.

When the Second World War came to a close, Helen and Curly were just coming of age in Iowa's rural farm country. The long shadow of the Second World War lengthened and darkened as the rivalry between the Soviet Union and the US, between East and West, between communism and capitalism, sharpened, and the beginnings of a proxy war on the Korean peninsula started to materialize.

Meanwhile in America's heartland, Helen graduated from high school in 1946, then went on to get her two-year teaching degree at Iowa State Teachers College. Curly graduated from high school in 1947, and went to work on the family farm alongside his father. In 1948, upon finishing her degree, Helen moved to Scranton, Curly's hometown, to begin teaching school. They met at the town's Homecoming Dance on October 1, 1948, 
and thus began their 67 -year romance. They ultimately had four children and five grandchildren: Helen and Curly were my maternal grandparents. Representing both descendant and historian, I have reflected below on my attempt to write an academic historical work on the relationship of my grandparents with scholarly integrity and respect for the subjects.

The letters, and therefore this paper, are set in the context of the Korean War, a sub-chapter in the larger Cold War conflict. Some scholars refer to the Korean War as "the most important event of the early Cold War." ${ }^{2}$ For Americans, this new conflict came on the heels of years of warfare, and it came with the possibility of sending soldiers to a foreign country once again. Helen and Curly's relationship escalated alongside Cold War tensions in Korea. Occupied by the US and the Soviet Union since the end of the Second World War, Korea stood divided in 1949 with the North Korean (Democratic People's Republic of Korea) and South Korean (Republic of Korea) governments sitting at "opposite ends of the political spectrum," each supported by their respective superpower. In June 1950, North Korea attacked the South in hopes of using military force to reunite the two sides, and South Korea, along with the United States, answered swiftly in kind. ${ }^{3}$

The first year of the war was intense and dynamic, featuring back and forth offensives and the surprise intervention of China on behalf of Communist North Korea in November $1950 .{ }^{4}$ Casualties accumulated quickly in the early stages of the war, as the front line moved dramatically and rapidly across the Korean peninsula. ${ }^{5}$ Then in June 1951, the war settled into a stalemate, which lasted until it came to an end with the signing of the Armistice in July $1953 .{ }^{6}$ With the fighting stabilized around the $38^{\text {th }}$ parallel in mid-1951, it became a war of attrition, with significantly fewer casualties. ${ }^{7}$ According to scholar Xiaobring Li, this period has become "the most forgotten phase of the "forgotten war." ${ }^{8}$ Curly was drafted in April 1951, and immediately commenced writing letters to his girlfriend. He was sent into the war of attrition after thirteen months of training stateside (see Figure 1).

Helen and Curly's war letters are not what initially come to mind when one says "love letters from war." They do not tell of epic battles, heroism, or bravery, nor do they include poetic promises to meet again in another life. Instead, Helen and Curly wrote to each other about rather banal matters: the weather, when he had watch duty, the happenings at her school, the USO (United Service Organizations) shows he saw. This diversion from the stereotypical tragic war letters was in part due to the stalemated nature of the Korean War from 1951 onward. "'Things were pretty stable when I was there,"” said Curly in a 2015 interview with a local newspaper. ${ }^{9}$ Additionally, due to the nature of his position, he did not see much combat. He served with the $2998^{\text {th }}$ Engineer Treadway Bridge Company, a part of the Army's X Corps, where his job was to train frontline soldiers in the basics of bridge-building. ${ }^{10}$ In one letter he wrote of an excursion 


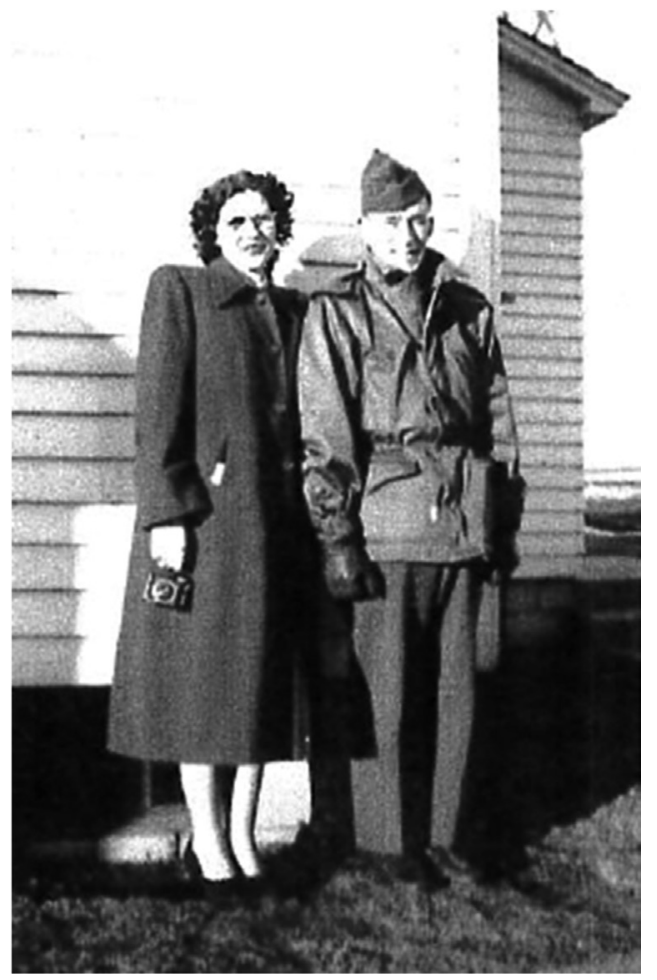

Figure 1: Helen and Curly in Scranton, Iowa, before he shipped out to Korea, March 1952. Source: Private Collection of the Helen and Curly Eason Family.

he took with a few fellow soldiers on one of his days off up toward the front lines, an anecdote which demonstrates both the physical and emotional distance between him and the intense fighting on the front lines. ${ }^{11}$ Thus, their letters are, in the words of English scholar Christopher Hager, "filled less with drama than with the ebb and flow of seasons, illnesses, and the simple passage of time," and show "little of what normally seems historically significant - leaders, battles, politics." ${ }^{\prime 2}$

An additional reason for the absence of content specifically relating to the war, particularly in Curly's letters, could be due to censorship for security reasons. While there is no evidence of official censorship in any of the letters from Curly, such as blacked-out text, it is plausible to suspect that he was following standard Army practices of self-censorship, knowing that his letters home would be subjected to censorship by military personnel. ${ }^{13}$ Thus, while the explanatory power of these letters regarding specifics of the Korean War is limited, the letters are a product of the 
conditions imposed by the Korean War, and indeed would not have been written at all had the Korean War not occurred.

Communications scholar Christina Knopf echoes the value that Hager places on the ordinary-ness of many historical, personal letters when she notes that "the sharing of daily life with another across a distance is at the heart of letter writing." 14 This analysis is primarily concerned with this recounting of Helen and Curly's common, daily lives. Through their written discussion of ordinary topics, in part facilitated by the relatively benign conditions of his deployment, they were able to use "their correspondence to nurture their sense of a shared identity."15 This shared identity, as fostered through their letter-writing, is the subject of inquiry of this project.

This article explores the following research questions: How did Helen and Curly preserve, and even grow, their connection when the conditions of the time forced a separation of time and space onto their relationship? What aspects of their relationship were they able to conduct through letter-writing? How did the Korean War and the larger Cold War affect servicemen's relationships? How did Helen and Curly react to the specific historical conditions of separation that affected them and forced their relationship to operate across borders? These questions help to direct the analytical narrative of this paper.

The paper proceeds according to the following organizational structure. First, the existing relevant literature is explored, serving to situate this work as an important and unique contribution to the academic literature. Second, an analytical section looks at some theoretical and methodological questions relating to a project of this variety. It includes an examination of the use of personal letters in historical and biographical writing, in addition to reflections on the author's personal connection to the subjects, as well as the microhistorical approach that is employed. The remaining part of the paper is devoted to analyzing the letters, to showing the written aspects of their relationship on a timeline of Curly's service and in the context of larger trends of the time. The analysis reveals how the institution of marriage partially mitigated the insecurities of the future; how they used their spirituality to cope with adversity; and how they engaged in long-distance planning for a life of farming together upon his return home.

\section{PERSONAL EXPERIENCES OF WAR}

Because this study is situated at the intersection of history and life writing, it is within this cross-section of scholarly literature that this study 
needs to be contextualized. Historiographic literature on the Korean War abounds ${ }^{16}$ but only a limited number of personal voices from the war are heard through the cacophony of diplomatic and political histories. One example is a well-known book written by T.R. Fehrenbach, This Kind of War: A Study in Unpreparedness. It is primarily based on the personal narratives of soldiers themselves, and tells the story of the Korean War through soldiers' accounts of intense combat. ${ }^{17}$ This approach edges toward the realm of life writing with the inclusion of personal narratives, but the questions asked by the author are centered on military combat rather than on personal experiences. Carol Kelly's article "ROA remembers the forgotten war: Korea" also follows the same vein, using troops' accounts to recount military-related affairs in Korea.$^{18}$ Additionally, there are some collections of letters written home from soldiers in Korea that have been published online, but these collections let the letters speak for themselves, by refraining from including historical or life writing analysis. ${ }^{19}$

A handful of scholars have researched personal experiences in the context of other wars by combining a historical and life writing analysis. Historian Kate Hunter has studied the letters between an Australian soldier and his loved one back home during the Great War, and English scholar Christopher Hager has analyzed the letters written home by Northerners and Southerners who were fighting in the American Civil War. ${ }^{20}$ Another example of work based on letters of war is Christa Hämmerle's contribution to Rebecca Earle's edited volume, Epistolary Selves, which examines one Austrian couple's correspondence during the First World War. ${ }^{21}$ Historian Martha Hanna's 2006 book based on the letters of a French peasant couple also during the Great War argues that a history that has "previously been viewed only through a wide-angle lens," can benefit from a microhistorical analysis. ${ }^{22}$ This small collection of studies demonstrates the value of using insights gleaned from the letters between soldiers and their loved ones to illustrate more deeply, and in a different light, the conditions of the respective war which each text investigates.

This study builds on the work of the aforementioned scholars by further illustrating how a life writing approach can help historians to ask and to find answers to different types of questions. The classic historiography, in this case on the Korean War, is lacking in historians' interpretations of Americans' personal experiences. By underscoring the significance that written correspondence had for Americans who were separated from their loved ones in the early Cold War era by geopolitical conditions, this article uniquely contributes an understanding of the impact that the needs of the American state had on one young couple, and presumably scores of others like them. On the broader scale, this analysis amplifies 
the voices from the bottom, of people who continued to live their daily realities and conduct their personal relationships through penned letters - voices which deserve to be heard. This project will add an understanding of how Americans, both in Korea and back home, experienced this tumultuous time. By investigating how one young American serviceman and his sweetheart sustained their relationship through the epistolary tradition, this article contributes to the existing historiography both on the Korean War and on the conditions that it created for young adults living in early Cold War America.

\section{LETTERS AS SOURCES, FAMILY AS SUBJECTS}

\section{PERSONAL LETTERS AS SOURCES}

The letters written by Helen and Curly from 1951-1953 are the core source material for this life writing project. Using personal letters as sources presents both opportunities and challenges for the modern historian, as personal letters can be intimate and private. Often, as in the case of Helen and Curly's letters, they were written with a singular reader in mind: the person whose name is at the top of the page. Unlike newspaper articles, novels, court files, and other kinds of primary sources of the time, it is unlikely that these letters were written with a collective audience in mind. ${ }^{23}$ And most certainly, these letters were not written with the expectation that a historian would eventually read them. Miriam Dobson writes that when historians pore over letters from years past, "we feel we are breaking the ties of confidentiality and unlocking the mysteries of a past age." ${ }^{24}$ These letters shed light on Helen and Curly's relationship, and thus have explanatory power for Americans in the Korean War era, but only after the source material and source medium have been critically evaluated. What follows in this section is the necessary critical evaluation of personal letters.

Letters, much like photographs, capture a certain feeling, dynamic, time, and place. Once sealed and sent, they are frozen in time, like "flies in amber." ${ }^{25}$ This quality of letters is acknowledged by Helen in one of her early letters. While expressing feelings of insecurity about her letters, she wrote that she promised herself to seal her letters so that she couldn't tear them up or change them before sending, to preserve their authenticity. ${ }^{26}$ Helen and Curly's habit of writing the time, in addition to the date, in the top right corner of the letters, also serves to emphasize this frozen-in-time quality. These time indicators helped to transport the intended reader, either Helen or Curly, to the precise moment in time in which the letter was written. Helen also strove to transport Curly to the precise spatial 


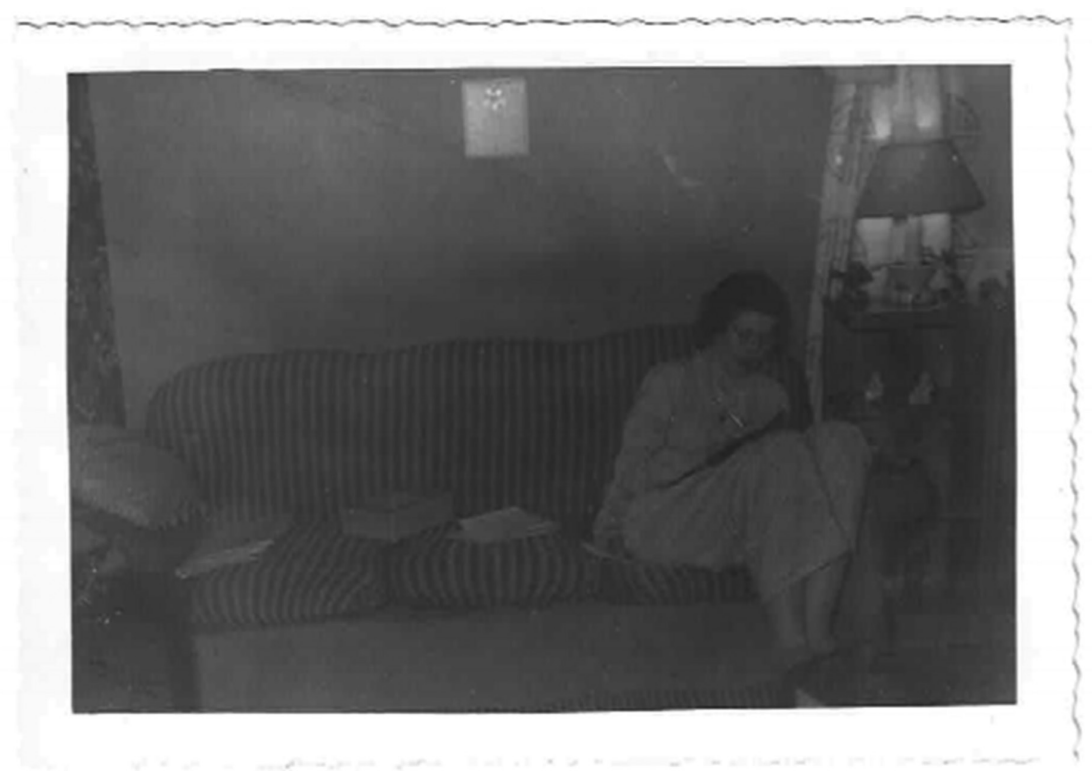

Figure 2: Photograph of Helen in her favorite writing spot: the corner of the Davenport in her apartment in Scranton, Iowa. Sent with her letter dated April 12, 1951.

moment in which she wrote her letters, when she sent two pictures of herself in the corner of the sofa in her apartment where she wrote her nightly letters to him (see Figure 2). ${ }^{27}$ These characteristics demonstrate that they were, at least on some level, aware of the "flies in amber" qualities: that these letters represented their thoughts at a particular moment and time in history, and that the letters, much like the photographs Helen sent, were snapshots in time.

When utilizing letters, historians must acknowledge their uneven, fragmented nature. The full exchange between Helen and Curly for the entire two-year period is inaccessible. From his eleven-month deployment in Korea, only his letters to her still exist. Letters addressed to a war zone are often not brought home by the soldier, due to challenges relating to storage, preservation, and portability of personal effects. ${ }^{28}$ Additionally, only her letters to him still exist for part of their correspondence while he was at training in the US. The only period for which both sides still exist is a five-month period in the fall of 1951. It is, however, possible to read into the other missing side of the correspondence based on the one existing side, as historian Martha Hanna 
has demonstrated. ${ }^{29}$ While the historical integrity of filling in the gaps using tools like extrapolation and imagination is debated, ${ }^{30}$ the collection of Helen and Curly's letters, in its entirety, supplies sufficient evidence to build a biographical sketch of their relationship, as one side of a dialogue can naturally shed light on the missing side.

Another aspect of the fragmented nature of personal correspondences, as discussed by sociologist Liz Stanley, is that correspondences are often examined by scholars as "“a whole' or 'a collection." 31 Individual letters never existed in this form, nor were they ever conceived of in this form at any point in the process of creation or consumption by the intended recipients. Stanley writes about the paradoxical nature of our practice of looking at fragments and attempting to see them as a whole. Christopher Hager critiques the practice of Civil War historians who search through archives of letters to find singular quotes that constitute the perfect argument: "stray quotations cannot capture the unfolding story, whose traces are scattered across months or years of letters, in which evolving thoughts and feelings, both personal and political, are interwoven." ${ }^{2}$ Both Stanley and Hager support the attempt by the scholar to examine epistolary fragments as a whole, but Stanley in particular acknowledges the potential limits of comprehending a series of letters as a single entity. ${ }^{33}$ While bearing in mind the unique properties of a collection of letters, the goal of this project is to locate and explore the threads of Helen and Curly's relationship that ran through their letters and kept the fabric of their relationship strong during a time of prolonged separation.

\section{CONFRONTING MY PERSONAL, EMOTIONAL CONNEGTION}

Often, family history falls under the purview of amateur historians who are curious about their predecessors. Professional historians, on the other hand, have tended to shy away from using their own family members as subjects of historical analysis. Historian Erla Halldórsdóttir asks who has the right to interpret a person's life, the historian or the descendants? ?4 $^{34}$ She writes of asking her historical subjects, "Can I do you justice... Can I use your private letters in my research without taking your experience, your words and life out of context? Will I honor your memory and treat these sensitive sources with respect and understanding?"35 These are crucial factors that I have considered as I constructed my own interpretation of Helen and Curly's lives.

There are, in fact, several scholars who have undertaken the difficult, yet rewarding, task of producing life writing based on their families. Historian Jeremy D. Popkin is among these scholars, and he states that an 
engagement with this kind of work can "never be objective and disinterested." ${ }^{36}$ While sociologist Ashley Barnwell acknowledges that scholarly accounts of family histories have the danger of becoming too indulgent or too sentimental, ${ }^{37}$ cultural theorist Leena Kurvet-Käosaar writes of welcoming the opportunity to subject the life writings of her family to academic analysis, an effect she describes as "comforting," and akin to the attitudes of other life writing scholars. Kurvet-Käosaar further notes the extensive knowledge that she has gained from the scholarly contextualization and analysis of a correspondence between two of her relatives. ${ }^{38}$ These scholars all recognize the potential explanatory power that is vested in personal familial sources.

Halldórsdóttir reflects that "in history itself there are emotions, and history evokes emotions." She argues that the writing of life stories by historians necessarily involves emotions and tendencies towards emotional attachment. ${ }^{39}$ Therefore, the consideration of emotional distance must be constantly confronted by all historians, regardless of whether or not their subjects are family, a sentiment echoed by Popkin. ${ }^{40}$ The topics of historical objectivity and the place of the self in history writing have been the subjects of considerable debate. ${ }^{41}$ Historian John Demos reflects on the 1950s creed of the model scholar "who keeps vigilant guard against every whiff of bias," and circles back around to note that for the modern historian, "to miss the connection [between the scholar and historical actor] is to lose one of the best reasons for being a historian in the first place." ${ }^{22}$ Popkin specifically notes the work of Lydia Flem, reflecting that her work emphasizes that a scholar's personal proximity to his or her subjects and materials requires investigation. ${ }^{43}$ As scholars and historians continue to reflect on and debate the complex relationship between researcher and historical subject, the overarching key is that an active examination of the relationship is crucial. It is in accordance with this scholarly imperative that I have explored the elements of historical objectivity in this project.

In one way, the subjects of this study are people that I never knew. The subjects of this project are not post-retirement Helen and Curly, the grandparents of my childhood. Instead, the subjects are Helen and Curly in their early 20s. These were people that I never met. They were living in a time I didn't know, with people I never knew, under conditions I never experienced. Instead, I knew the people they would become near the end of a lifetime lived, not the people they were when they stood on the precipice of adulthood. I was born in 1994 when they were in their mid-60s, and they passed away in 2016 and 2017, both at the age of 88 . I first began work on this project in 2018. This situational and temporal 
distance corresponds to an important emotional distance between myself and my subjects.

Another element of emotional distance that exists in this project is the narrative voices of the letters for me as the researcher. The narrative voices of the letters that I adopted internally while reading them was that of a young couple in the 1950s, they are not the voices of my grandparents as I remember them. However, in an instant, all that emotional distance can come crashing down. These instances are instigated by small phrases that are so intimately familiar to me, that the narrative voice suddenly becomes a voice I know, and miss. Perhaps the best example of this was when Helen opened a letter with: "Hang onto your hat! I am really wound up tonight. I feel like I could talk all nite." ${ }^{44}$ These kinds of moments for me are what Baldvin's tear was for Halldórsdóttir, and what Webster's hair was for Lepore. ${ }^{45}$ These are instances when, to quote Halldórsdóttir's eloquent description, "the past seems to materialize in our hands, when words in an old letter pierce their way into our mind as though they have been written yesterday, or at this very moment." ${ }^{46}$ Materiality elements accompany working with personal letters of any kind. But as a historian with the additional role of descendant, I have struggled more acutely with the materiality elements of this project and the accompanying emotions than another historian might have.

Confronting my personal and emotional connection to the subjects then has been absolutely crucial as I have endeavored to create a scholarly contribution based on these sources that my grandparents left behind. While a personal connection of any kind between historian and subject can be argued to "violate history's rules with impunity," ${ }^{77}$ I have striven to maintain a critical distance from my subjects, because to have their artifacts and their story speak to the larger historical understanding, this distance is vital.

The first person style of this section has been largely modeled on the intimate style employed by Halldórsdóttir in her two pieces reflecting on historians' use of personal letters. These pieces contain her thought processes as she conducts historical research, and thus the first-person narration is crucial for the purpose of the articles. ${ }^{48}$ Halldórsdóttir models how a historian should confront, not deny, the existence of his/her own emotions. In mirroring the short distance between historian and subject, Halldórsdóttir also writes in a way that shortens the distance between historian and reader. She writes that it is "inspiring to face our interpretational problems openly by writing about them and to reflect on our research process, how we produce knowledge (history). Hence, we are better able to sort out our sources, how we relate to the subject." ${ }^{49}$ In this way, parts of this methodological section represent the process of emotional confrontation that 
I have undertaken throughout the course of this project, and have been written in a necessarily personal style. An exploration of these kinds of reflections ensures the integrity of the rest of the work, as methodological aspects centrally inform the analytical sections.

\section{MICROHISTORICAL APPROACH}

This article employs a microhistory approach. Closely related to biography, in that it is also a form of life writing, microhistory is a product of the rise of social history in the 1970s and 1980s which advocated for a history from the bottom. While historian Barbara Caine sees merit in accepting the similarities between the two sub-fields, centrally of valuing the explanatory capabilities of individual lives, ${ }^{50}$ there are meaningful differentiations between the two fields. The subjects of microhistory are, in the words of historian Lisa Lindsay, "interesting because they were ordinary" which stands in stark contrast to the subjects of biography who tend to be more valued for their uniqueness, for some extraordinary trait, characteristic, or position they held. ${ }^{51}$

Microhistory subscribes to the idea that history is made by a wider range of people than just elites, and therefore that the examination of a previously unknown individual's life can serve as an "allegory" for the experiences of a culture as a whole. ${ }^{52}$ Indeed, implicit in the word "ordinary" is the understanding of "normal," meaning not deviating from the standard, and therefore like others, i.e., representative. Other scholars are also in agreement with this perspective: that the previously unknown subjects of microhistory can be said to be representative of their peers, and that it is precisely in this representativeness that the illustrative power of their stories lies. ${ }^{53}$ The debate on representativeness vs. uniqueness is an active and fruitful dialogue in the life writing discipline. One historian in particular, Sigurður Gylfi Magnússon, has voiced a contrasting view that even for previously little-known subjects, the microhistorical approach is valuable for highlighting the unique aspects of the person, without necessarily needing to be related to the grander narratives and perspectives of history. ${ }^{54}$

This article, however, takes the fundamental stance that Helen and Curly are, as until now relatively unknown historical agents, representative of their peers. The insights gleaned from their letters are meaningful because they can reasonably be applied to couples who come from similar backgrounds and from the same time period. That is not to say that their experiences and expressions exactly mirror those of other young American couples separated by the Korean War. Helen and Curly were 
individuals, just as their peers were too. However, in keeping with historian Jill Lepore's assertion that most microhistorians "look at their subjects as faintly exotic but somehow emblematic," 55 this project contributes to our understanding of the ways that the letters between servicemen and their sweethearts served to communicate and to develop their relationships through the epistolary tradition during the Korean War, precisely because the story of Helen and Curly is both "ordinary" and "emblematic."

\section{TRANSNATIONAL NATURE}

As the transnational turn has flourished in recent years, historians have debated the nature of transnational history. At its core, "transnational" is generally agreed upon to describe and encompass trends, movements, flows, and patterns that operate without respect for national boundaries. For some, the term "transnational" opens previously little-known realms of history that are best seen through the fresh lens that a transnational approach provides. ${ }^{56}$ For others, like historian Ellen Fleischmann, "transnational" in its most traditional sense can instead be constricting. Fleischmann argues that within grand transnational narratives about currents of people, goods, and ideas, there is little room for the stories of the individuals. ${ }^{57}$ However, she ultimately is able to consider "transnational" in a "more internal, individualistic, and personal sense." ${ }^{58}$ This approach is helpful when determining an analytical lens to conceptualize Helen and Curly's correspondence.

Prior to the Korean War, Helen and Curly were distinctly nontransnational characters from small-town rural America. They only became transnational actors due to the larger geopolitical situation of the time, and for just a brief period. Curly was part of a mass flow of people overseas; he was one of 6.8 million American troops who served in the Korean conflict. ${ }^{59}$ Additionally, the Korean peninsula was, at that time, a geographic area in which national borders were very much in question. Helen and Curly wrote letters that sustained their emotional connection and commitment to each other across space. Their letters, especially while he was stationed in Korea, travelled as airmail across the vast expanse of the Pacific Ocean. In sum, Curly was a transnational actor in a global conflict, and Helen supported this role through the maintenance of their relationship. Curly was training for, then acting as a belligerent in a foreign war, while keeping his roots planted firmly in the home front of a nation at war through their shared correspondence.

However, the transnational nature of these subjects is also limited, in the sense that although Curly was geographically located in a foreign country, he had virtually no contact with Korean culture, as far as the 
letters reveal. The American base provided an "American" environment that is characteristic of US military installments around the world ${ }^{60}$ thus placing him in a quasi-foreign location that was several thousand miles away from home. Though Helen and Curly were separated by a temporal and a spatial distance, the relevance of the international borders that existed between them should not be overstated. This is a peculiar feature of the situation that the letters describe, and must be accounted for when evaluating the transnational nature of these subjects.

\section{BUILDING A RELATIONSHIP IN THE FACE OF UNCERTAINTY}

\section{SPRING AND SUMMER 1951: COMBATING INSECURITY WITH INTIMACY AND MARRIAGE}

The early letters from Helen and Curly's first months of separation reveal the sense of uncertainty that pervaded their relationship at the time because of the conditions imposed by a nation at war. Only Helen's half of the correspondence from this time still exists. This section detailing the spring and summer of 1951 uncovers a few key areas of uncertainty that Helen (and Curly) experienced, and subsequently explores some key solutions that they found to help mitigate the effects. The process of learning to cope with the uncertainty of the times and conditions of their lives is the story of Helen and Curly in the early 1950 s.

Helen wrote of her concerns about when Curly would be sent overseas. This is a recurring theme in their letters: an uncertainty about what the future held in terms of where he would be stationed and when he would go overseas. Early in April, soon after he left for training, Helen wrote "All I could think about was 'when will he be sent."” ${ }^{16}$ From April until August, Curly was stationed at Fort Leonard Wood in Missouri. In July, when he found out that he would be transferred to Fort Belvoir in Virginia, she wrote "I always think of you going to Virginia but always in the back of my mind is the fact that you may go overseas." 62 His geographic location in the future was just one of many questions that simply did not have answers in the spring of 1951.

An excerpt from a June letter illustrates Helen's interpretation of the larger uncertainties of the times:

In some of your letters you have asked about the news. Honey, I can't tell you what is happening in the world. The papers and radio keep everyone so mixed up, especially me, I couldn't explain it if I had to. The only thing I know for sure is that they are fighting in Korea and I wished to heavens 
they weren't. Then everyone could go home to the ones they love and lead a normal life. ${ }^{63}$

In this, we can see the confusion surrounding the media coverage of the war and the general geopolitical situation. Furthermore, Helen expressed a yearning for "home" and "a normal life." This statement echoes the thesis of historian Elaine Tyler May in her book on American families in the Cold War: "For in the early years of the cold war, amid a world of uncertainties brought about by WWII and its aftermath, the home... held out the promise of security in an insecure world." ${ }^{4}$ May cites demographic statistics that indicate that Americans in the early Cold War period were "more eager than ever to establish families." ${ }^{15}$ The marriage age declined as compared to previous historical periods, as almost every young American was married by his or her mid-twenties. ${ }^{66}$ Further, the marriage rate accelerated in the late 40 s and early 50 s, incited in part "by the imminence of the men's departure for foreign shores." ${ }^{67}$ For many, marriage was thus a remedy for the insecurity of post-war, early-Cold War America.

Helen and Curly's short engagement and subsequent marriage while he was on leave from boot camp can be seen in the context of this larger societal trend. May writes that marriage offered a remedy for the general insecurity of the 1950s. The first mention of their engagement was in one of Helen's letters from June 1951, just after they had spent a weekend together. ${ }^{68}$ The letters between this time and their wedding, on August 1 , 1951 (see Figure 3), tell the story of their yearning for marriage to, in May's words, "solidify their relationship and establish connections to the future" in the face of his impending deployment overseas. ${ }^{69}$

These early letters also include a number of references to sexual intimacy, which demonstrates how Helen employed expressions of sexual desire as a way to continue building their relationship while being physically separated. As early as April $19^{\text {th }}$, 1951 , Helen wrote "As far as myself, I'm fine except that a little lovin' couldn't cure. And I have a good imagination and I am sure using it." 70 This is one of several instances where Helen explicitly states sexual desires prior to their wedding, ${ }^{71}$ and these types of references also continued after they were married, including from Curly while he was stationed overseas. ${ }^{72}$

It could be argued that their marriage was in part motivated by a wish to legalize sex, given the stricter sex-before-marriage customs of the era. However, Helen and Curly's letters suggest they had already achieved a high degree of sexual intimacy prior to marriage. This suggestion hints at a relatively progressive departure from the more traditional sexual norms of the time, though the full extent of their intimacy remains vague in the letters. Notably absent in the letters are sentiments of longing for ultimate benefits of the conjugal bed, that is, the mentions of sexual desire 


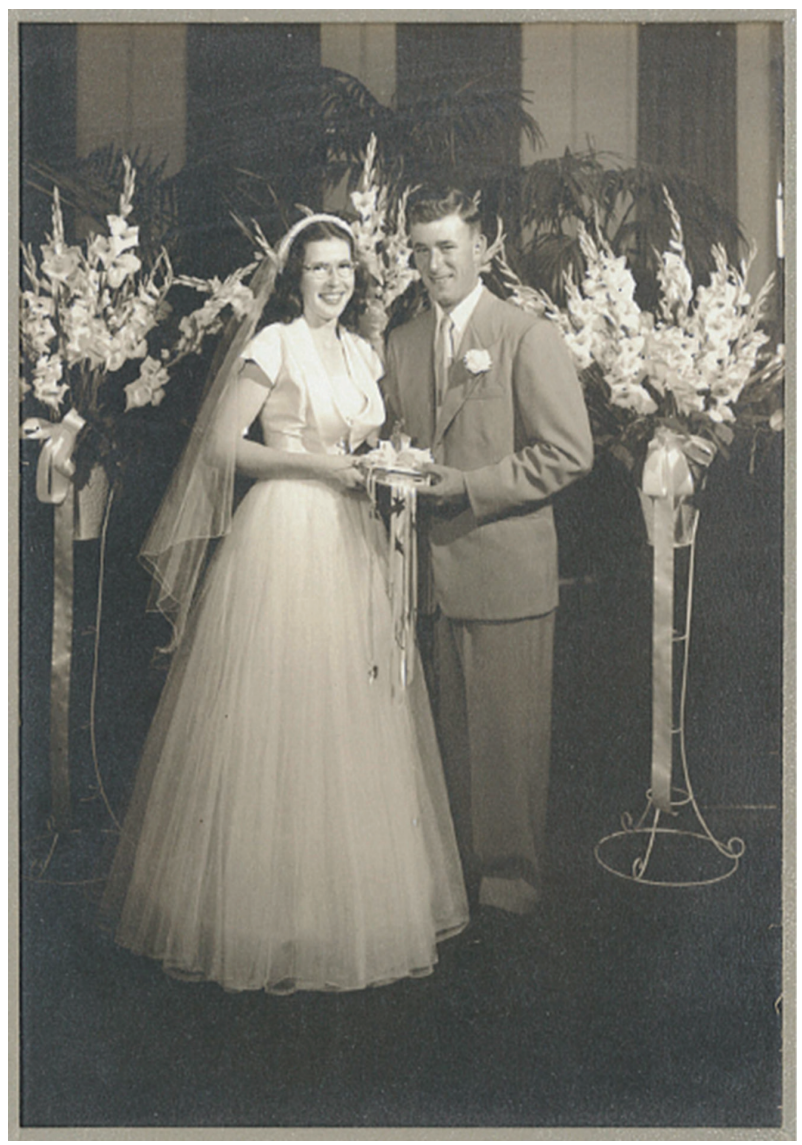

Figure 3: Helen and Curly on their wedding day, August 1, 1951, at the Collins United Methodist Church in Collins, Iowa.

Source: Private Collection of the Helen and Curly Eason Family.

read instead as general longing for their distant partner. This indicates that their urge to marry when he was home on leave was likely more for reasons of security and cultural norms than primarily for reasons of legitimizing or allowing sexual relations. The marriage statistics from the 1950s unequivocally indicate that Helen and Curly were on a parallel chronological course with their peers who were also charting the difficult and uncertain waters of the early Cold War. ${ }^{73}$

After the engagement in the beginning of June, many of Helen's letters are dominated by chatter about wedding planning, as the wedding was a day in the future to which they could, and did, look forward, and 
especially for Helen, the planning was a labor of love. "If we expect to be married the first week in August, I'll have to have everything in mind and pretty well organized by the second week in July," she wrote in mid-June. ${ }^{74}$ Also in that same letter she wrote: "As the old saying goes 'You're too far in to back out now.' I guess that isn't right cause you could back out but I don't think you will. I think you want us to be 'one' just as much as I do. It will be so wonderful to know we really do belong together. No one can take that from us, no matter what is said or done."75 In her words, we see Helen's craving for the finite unity that their marriage would bring. When she said "no one can take that from us," she might also have said "no war or condition can take that from us." To Helen, the marriage would bring validation and security, making her emblematic of her 1950s American generation.

However, Helen's desire for security exceeded what a marriage could provide. She knew that their married life together would not start in the truly conventional sense until he was out of the military. She expressed these hopes and dreams in her letters to him framed in the context of a future down the road, instead of a near future. In June, when talking of her parent's house in the summertime, she said "It really seems like a cozy little home now. Maybe someday we can have a home." 76 Again, about a month later: "I haven't decided where I am going to store all of this stuff until we do have a house. That day will be another wonderful day. When we can really settle down." ${ }^{77}$ Even though their impending marriage was just around the corner when she wrote these sentiments, an unknown number of letters still stood between them and a life lived together, settled in a home. Still, these visualizations of a future together were powerful in building what Dobson calls their "sense of a shared identity." 78

The early letters from Helen depict an overall sense of learning to cope with the newness of having spatial distance between them. After nearly three years of being in a steady relationship and living in the same small town in rural Iowa, Helen and Curly had to adapt to the sudden change of circumstances that took their relationship, in Hager's words, "from the plane of the earth [to] sheets of paper." ${ }^{2}$ He continues, "Some crucial part of their experience of the war transpired... in a kind of no place aloft, along an invisible path traversed only by envelopes." ${ }^{80}$ Compounded by the geopolitical dynamics of the Cold War, Helen and Curly's anxieties were penned, and together they found solace in hope for a shared future.

\section{FALL 1951: BOUND TOGETHER BY SHARED LANGUAGE AND FAITH}

After their marriage on August $1^{\text {st }}, 1951$, "that wonderful day" ${ }^{81}$ as Helen later referred to their wedding day, it was clear that the newlyweds reveled 
in their newly married status. This is evidenced by the signing of most letters with "Your faithful and loving husband Curly," and "Your lovin' wife Helen," or some close variations thereof. This obvious love and devotion to each other is part of a larger continuity of affirmation of love and commitment throughout the full two-year period. Without fail, each letter includes a profession of just how much love the sender feels for the receiver. The frequency and strength of their avowals of love are perhaps a product of the condition of separation. Hunter writes that lengthy separation necessitated the development of "a language with which to express loving feelings," as a kind of a "psychological coping" mechanism. ${ }^{82}$ This is the case, she argues, especially for courting and newly-married couples. Without the security or continuity of years lived together as one, "separation forced soldiers and their lovers to become regular and faithful letterwriters or risk emotional and perhaps social estrangement." ${ }^{83}$ Helen and Curly's commitment to expressing affection and adoration is one component of a shared language they developed, and came to be a staple that bound them together during their time apart.

Another element of the shared language they developed was common memories that marked the passage of time in various ways, a demonstrated epistolary tool that serves to strengthen intimate bonds. ${ }^{84}$ On July 1, 1951, she wrote: "Darling, the last two years we were together on the $4^{\text {th }}$. I guess a lot of things will be changed." ${ }^{55}$ Then on July $4^{\text {th: }}$ "When I woke up this morning the first thing I thought of was how you got me up last year on the $4^{\text {th }}$. Do you remember? It was with a shotgun right under my window." ${ }^{86}$ The re-telling of shared memories is an important tool that strengthens relationships, especially those that function across space. ${ }^{87}$ On September $17^{\text {th }}$, Helen wrote in anticipation of October $1^{\text {st }}, 1951$, that that date was their anniversary in two ways: two months of being married and three years of knowing each other. ${ }^{88}$ This is evidence of an active engagement with and revisiting of the important dates of their shared past. Further, in a twist on the language of shared memories, Curly noted an anniversary of a different kind: "Today marks the beginning of the ninth month of service time for me. Only 16 more months to go and I'll be with you everyday until time runs out for both us." ${ }^{89}$ In these sentences, Curly utilized the time that they had spent physically separated from each other as a countdown to the time they could be together for the rest of their lives.

The letters from this period also reveal a secret system that Helen and Curly developed. All the envelopes prior to August 1951 have the stamps facing right-side up. However, from August onward, the stamps are upside down (see Figure 4). The explanation was buried in one of Helen's letters: "The stamp on the letter mailed today might not have been upside 


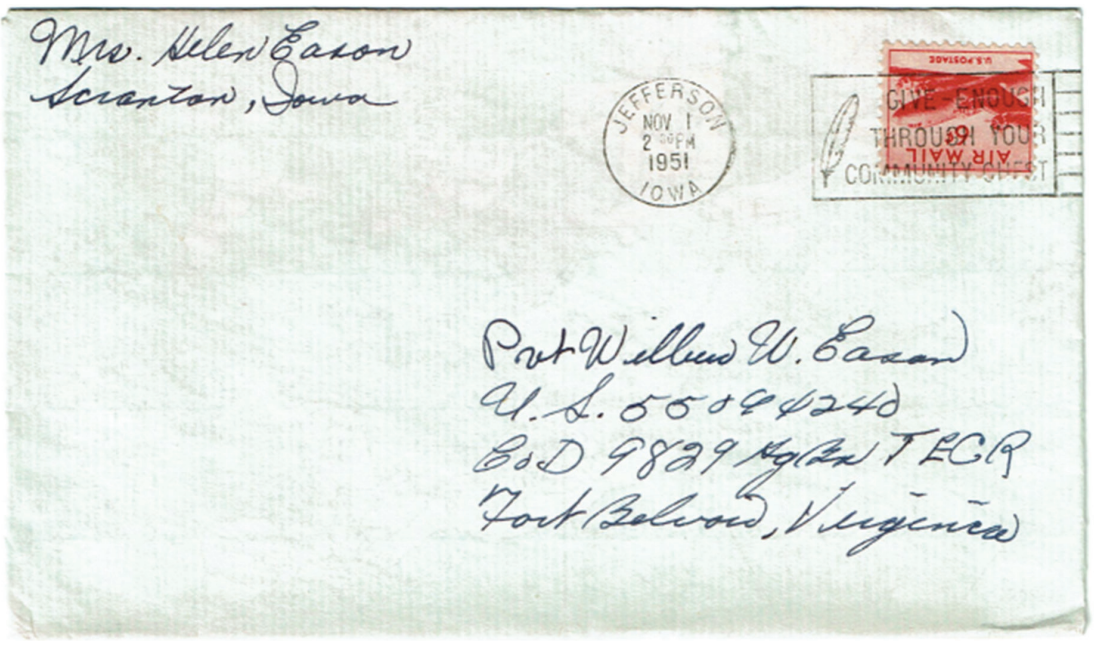

Figure 4: Envelope from Helen to Curly, postmarked November 1, 1951, featuring an upside-down stamp.

down. Mom or Dad put it on cause I left it here to be mailed. But I gave you extra thoughts today anyway." ${ }^{90}$ It is remarkable that she left such a clear explanation for such an intimate system that could have easily remained unexplained. This system indicates a desire to add an extra personal touch to their communication, and can be seen as an element of the special language that they developed to shorten in some way the distance between them.

For much of the fall, Curly was at cartography school at Fort Belvoir, Virginia. Their letters from September and October reflect the tension that he felt during this period. His letters referenced worries about passing the final course, ${ }^{91}$ while her letters were full of encouraging phrases such as: "Keep your chin up" ${ }^{92}$ and "I am trusting the Lord to make things come out right." ${ }^{\prime 3}$ Then, on November $10^{\text {th }}$, Curly wrote, "Darling I have something to write which is very very heartbreaking to me." He proceeded to tell her that he had failed the map-making course. "Believe me Darling the Bible gave me great consolation after I had heard what my score." ${ }^{94}$ This episode reveals Curly's religious commitment. Both Helen and Curly were lifelong Christians, and there are many examples of their religious devotion throughout their two-year correspondence. However, it was during this specific time, when Curly experienced a setback in his planned military career, that he sought and received solace from his spirituality. A week later, he wrote "Helen I've just come back from the Chapel after 
attending a fellowship meeting. I'm firmly convinced that with Christ leading the way we have a wonderful life ahead of us when I return to you. I love you very much. God has shown me that the best way is his way." ${ }^{95}$ With the use of a strikingly more positive tone, he demonstrated an acceptance of the past and a renewed hope for the future with Helen. Included in this letter was a pamphlet from the church service dated November $11^{\text {th }}$ (see Figure 5). On the top in Curly's scrawl it reads: "The day I needed faith so badly and was in the mood to receive it. I'll always remember it." ${ }^{\prime 6}$ This is

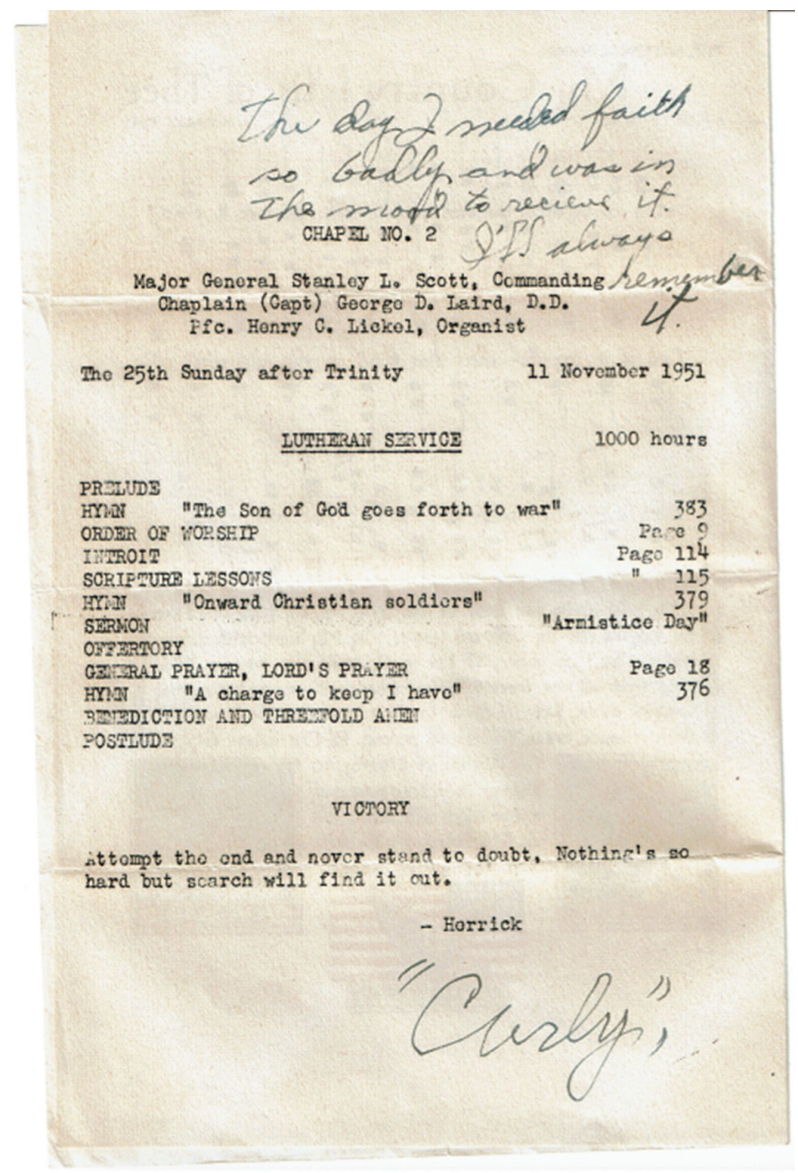

Figure 5: Annotated pamphlet from Church Service that Curly attended on November 11, 1951, the day after he wrote to Helen telling her that he had failed to pass the cartography exam. Sent with the letter dated November $18^{\text {th }}, 1951$. 
a testament to the power his faith played at a time of adversity. Reliance on his Christian faith was a strategy that Curly employed to cope with the challenges he faced, and it was also a tool of connection with his wife who was, at this point in time, halfway across the country.

The religious element of their letters is further explained by larger societal influences of the time. After the Second World War, the US population experienced a religious revival, that was stimulated to a large degree by government rhetoric. This rhetoric, which intertwined American exceptionalism with religious faith and the anti-communist crusade, resulted in an increase in visible religious practice and social expression of religion during the 1950s. ${ }^{97}$ Professed by American leaders including Harry S. Truman, Dwight D. Eisenhower, J. Edgar Hoover, John Foster Dulles, and George Kennan, historian Jonathan P. Herzog has called this systematic approach the "spiritual-industrial complex." 98 It is the resulting policy, Herzog argues, of a conclusion among American leaders that an America without religious institutions and beliefs was incapable of meeting the challenges of the Cold War, therefore necessitating the reinvigoration of religion in social and political structures. ${ }^{99}$ For the average American, this meant that "personal religious faith reflected proper patriotic commitment." 100

While Curly attended church regularly both prior to his military service and after, it is important to see his explicit turn to God in a time of need, while he was serving out his patriotic duty to his nation, in the context of this greater "spiritual-industrial complex" that gripped the US in the early Cold War. Separating the precise extent to which Curly's written words align with his actual beliefs is difficult, but these letters demonstrate that Curly does participate in this larger national rhetoric. This episode in his life is perhaps even more historically significant when understood in relation to the social and political environment that was being actively constructed in early Cold War America, than when only taken at face-value.

\section{WINTER 1952-1953: THE HABIT OF LETTER-WRITING AND PLANNING FOR HOMECOMING}

The final batch of surviving letters was written by Curly in Korea from November 1952 until February 1953, with the last letters written en route home. These letters are a window into Curly's experience in Korea. Unlike the earlier letters, they were sent across more than just a handful of states; they were sent across the expansive Pacific Ocean. There were no weekend visits for the smitten young couple, nor were there any occasional long-distance phone calls. For eleven long months, writing letters was their only means of communication. As the end began to come into sight, 
Curly's restlessness to get out of the Army became gradually more apparent, as evident in early January 1953: "I've now 21 months in Uncle Sam's Army. It don't seem so long but jove it has been. I'm really marking time now Darling. Won't be very long till I can have you in my arms instead of just in my head." 101 A few days later he wrote: "Honey I'm certainly having a time concentrating on the business at hand now. Time's growing so short. The Lt. told me tonight that Eason doesn't care much what goes on now because he's a short timer here. I told him he was so right."102 The final letters written by Curly detail the tactics he used to endure the remainder of his deployment in a foreign land, far from his sweetheart.

In the same local newspaper article from 2015 that was cited previously, Helen said, "I was teaching $5^{\text {th }}$ grade, I had lots to talk about." ${ }^{103}$ We can reasonably expect that her letters remained as upbeat and chatty as they were in 1951, containing stories from school events and gossip from friends and family at home. In his letters from Korea, Curly indicated just how much her letters meant to him. Every letter included a report on how many letters he had received that day, and according to the normal structure of his letters, this report came second, only after a variation on a few sentences indicating the deep extent of his love to her. In fact, in all the letters, even from Curly's periods of training in the US, both Helen and Curly wrote of the importance of the letters and of how much receiving one in the mail meant to them. There is a plethora of comments indicating both jubilation at receiving a letter, and disappointment when the mail delivery proved fruitless. Helen wrote about the power of letters in 1951, "I know how good they can make a person feel. I know what yours do for me. Mom says they are like a "tonic."'104 A tonic is an apt metaphor for the role that the letters played in both of their lives; however, it seems as though her letters were of acute necessity to him while overseas. Beyond just a tonic, they were a buoy to him, as evidenced in the letter from January $2^{\text {nd: }}$ "No mail for little ole me today. What you gonna do GI. Gosh I don't know I'm sure hoping I get a letter tomorrow. Cause my morale is getting sorta low if you know what I mean and I'm sure you do." ${ }^{105}$ Curly lived by the post and relied on it for his mental well-being, especially during his deployment overseas. ${ }^{106}$

Occasionally, Curly would write a response to something that Helen had written, but more often, he simply made note of having received any mail or not, and then proceeded with his own letter, detailing the weather, or the shows he had seen, or when he had had guard duty. Because they wrote nearly every day, their letters were less a conversation and instead were a habit of connection; a time of day that they each set aside to connect with the other. The diary-like purpose that the letters served for Helen and Curly has the effect of manifesting a diary-like quality in the letters themselves. Early in the correspondence, Helen wrote "Goodnite, 
Curly, I've talked to you in a sorta-way so now I can go to bed." 107 At another point she confessed "I wasn't going to write tonite but when I turned out the light and saw that moonlight, I got so lonesome. I knew I might as well talk to you for a while." 108 Twice she compares writing to talking, which is revealing that their letter-writing acted as a replacement for what otherwise would have been daily face-to-face contact. Curly once admitted "I'm slightly ashamed at myself for not writing since Tuesday evening," 109 further demonstrating the commitment they had to faithful letter-writing by revealing the shame that came when they failed to write.

In January of 1953, they began discussing plans for his arrival home. On January $5^{\text {th }}$, Curly wrote to Helen, "You asked in one of your letters what I was going to do when I get home," but then refrained from following up on the comment any further. ${ }^{110}$ Less than two weeks later, though, he informed her of progress on the planning for his return: "Imagine my surprise when at the end of father's letter he mentioned the fact that he was expecting me to farm the "Timber Lodge place." 111 On February $3^{\text {rd }}$, he mentioned the farm again, but informed her it wouldn't be final until he was home to sign. ${ }^{112}$ Three days later he wrote: "Honey we now or soon will have two farms rented. How do you like that. I do." ${ }^{113}$ He further elaborated on the deals, deliberations, and arrangements he had been having with his father, his "Grandad," and his younger brother in this uncharacteristically long two-page letter. Together, these letters demonstrate concrete planning and a focus on building their life together after his service.

Curly was planning his future around the only occupation he had known outside of being a soldier: farming. However, the concept of the family farm was undergoing significant change in the middle of the twentieth century. The exodus of Americans from rural farms to urban metro areas due to technological improvements in agriculture is a welldocumented trend. ${ }^{114}$ By 1950, the number of farms in America was well in decline from 1900 levels, while the size of farms had an inverse upward trend. ${ }^{115}$ Agribusiness, the corporate farming model, was the enemy of the family-owned farm by the mid-1950s. ${ }^{116}$ The romantic idea of the wholesome American family farm was in decline just as Curly was staking out his future in the root of that idea. Despite the declining prospects of achieving success on a family farm in Iowa in the 1950s, Curly persisted in working for the way of life that he knew. In a future of farming together, Helen and Curly saw more certainty than uncertainty.

\section{CONCLUSION}

According to historian Jill Roe, biography broadly "illuminates both the life and the times of its subjects, and, to put it more grandly, the human 
condition." 117 Microhistory, more specifically, studies "hitherto obscure people... to reveal the fundamental experiences and mentalities of ordinary people." 118 This historical study based on the letters of Helen and Curly Eason has sought to accomplish both of these aims: to illuminate and to reveal the life and times of two otherwise ordinary people, and therefore to elucidate the human condition through a combined life writing and historical approach.

Helen and Curly left a written trail of their relationship over the course of two years of separation. Correspondence, in the absence of time spent in each other's company, was how they nurtured and grew their relationship, which was still in the early stages when Curly left for training. The conditions of war inserted a separation into their relationship, as Curly was drafted to continue his nation's fight in Korea to keep Communism at bay. Helen and Curly had no choice but to transition from lives lived together, in person, to lives lived, then written down, post-marked, delivered, torn open, then read, reread, and cherished.

As a couple, they assumed various techniques to mitigate the effects of the distance between them, to soften the questions surrounding both imminent and distant futures, and also to allay the pervasive sense of uncertainty that consumed the US at the time. In the first months that they were apart, Helen's anxieties about what the future held came through clearly in her letters. She wrote about dreams of a home they would share someday in the future, and also fantasies and memories of their sexual relationship. She also wrote of more concrete wedding planning topics once they were engaged. As a young couple in the early Cold War, when many of their peers were getting married, Helen and Curly's marriage can be seen as a tool to mitigate feelings of societal insecurity.

As Helen and Curly settled in to their married life, new strategies to deepen their connection to each other emerge in the letters. These letters show how they were able to support each other, and build their relationship as it entered a new phase. They employed their own shared language of love; a language that incorporated a celebration of their newly married status, memories of happy times in the past, as well as the secret stamp system. Their shared belief in faith when faced with challenges also demonstrates the development of a shared value system.

While Curly was actually in Korea, they shared the perhaps mundane details of their daily life, as evidenced by the conversational style of the letters and by the reliance on the near-daily frequency of letter writing and receiving. Planning for their shared future, a normal aspect of an intimate relationship, was also conducted through their written correspondence.

By studying the micro-level trail of evidence left by one couple, this article illustrates how an American couple coped with the effects of their 
nation at war. This article also serves to demonstrate the validity of an analysis that is conducted even when the author shares a close familial bond with the subjects. While there is a familial connection between this author and the subjects of the inquiry, confronting that relationship and the questions surrounding objectivity has proven to confirm the academic integrity of this work. Returning to the initial research questions, this article has demonstrated how Helen and Curly relied on letter writing to grow their intimate connection to each other and still conduct various aspects of their relationship amid the impacts of their nation's participation in the Cold War, and more specifically, the Korean War. This investigation of the letters of Helen and Curly, two relatively ordinary people from the rural Midwest of the United States, illustrates the significance that epistolary correspondence had for American couples who were separated by the Korean War and living in early Cold War America.

\section{BIBLIOGRAPHY}

Barnwell, Ashley. "Working with Family Histories." Eds. Kate Douglas and Ashley Barnwell. Research Methodologies for Auto/Biography Studies. New York: Routledge, 2019. 76-82.

Bayly, C. A., Sven Beckert, Matthew Connelly, Isabel Hofmeyr, Wendy Kozol, and Patricia Seed. "AHR Conversation: On Transnational History." The American Historical Review 11.5 (2006): 1441-1464. DOI: 10.1086/ahr.111.5.1441.

Bevir, Mark. "Objectivity in History." History and Theory 33.3 (1994): 328-344. DOI: $10.2307 / 2505477$.

Blower, Brooke L. "Nation of Outposts: Forts, Factories, Bases, and the Making of American Military Power." Diplomatic History 41.3 (2017): 439-459. DOI: 10.1093/dh/dhx034.

Boose Jr., Donald W. and James I. Matray, Eds. Ashgate Research Companion to the Korean War. England: Ashgate Publishing Limited, 2014.

Caine, Barbara. Biography and History. Hampshire: Palgrave Macmillan, 2010.

Canipe, Lee. "Under God and Anti-Communist: How the Pledge of Allegiance Got Religion in Cold War America." Journal of Church and State 45.2 (Spring 2003): 305-323. DOI: $10.1093 / \mathrm{jcs} / 45.2 .305$.

Cherlin, Andrew J. "American Marriage in the Early Twenty-First Century." The Future of Children 15.2 (Autumn 2005): 33-55. DOI: 10.1353/foc.2005.0015.

Clark, Donald N. "Reviewed Work: The Unwanted Symbol: American Foreign Policy, the Cold War, and Korea, 1945-1950 by Charles M. Dobbs." The Public Historian 6.1 (1984): 81-83. DOI: $10.2307 / 3377693$.

Demos, John. "Using Self, Using History..." Journal of American History 89.1 (June 2002): 37-42. DOI: $10.2307 / 2700781$.

Dimitri, Carolyn, Anne Effland and Nielson Conklin. "The $20^{\text {th }}$ Century Transformation of US Agriculture and Farm Policy." United States Department of Agriculture, Economic Research Service, Economic Information Bulletin No. 3 (2005): 1-14.

Dobson, Miriam. "Letters." Eds. Miriam Dobson and Benjamin Ziemann. Reading Primary Sources: The Interpretation of Texts from Nineteenth- and Twentieth-Century History. New York: Routledge, 2009. 57-73.

Eason, Curly, and Helen Caulkins Eason. Letters. 1951-1953.

Fehrenbach, T.R. This Kind of War: A Study in Unpreparedness. New York: Bantam, 1963. 
Fleischmann, Ellen. "II Only Wish I had a Home on this Globe': Transnational Biography and Dr. Mary Eddy." Journal of Women's History 21.3 (2009): 108-130. DOI: 10.1353/jowh.0.0090.

Gartner, Scott Sigmund and Gary M. Segura. "War, Casualties, and Public Opinion." Journal of Conflict Resolution 42.3 (June 1998): 278-300. DOI: 10.1177/0022002798042003004.

Hager, Christopher. I Remain Yours: Common Lives in Civil War Letters. Cambridge, Mass. and London: Harvard University Press, 2018.

Halldórsdóttir, Erla Hulda. "Fragments of Lives - The Use of Private Letters in Historical Research." Nordic Journal of Women's Studies 15.1 (2007): 35-49. DOI: $10.1080 / 08038740701253551$.

Halldórsdóttir, Erla Hulda. "Baldvin's Tear. The Materiality of the Past." Eds Izabella Agárdi, Berteke Waaldijk and Carla Salvaterra. Making Sense, Crafting History. Practices of Producing Historical Meaning. Pisa: Plus-Pisa University Press, 2010. 207-219.

Hamilton, Shane. "Agribusiness, the Family Farm, and the Politics of Technological Determinism in the Post-World War II United States." Technology and Culture 55.3 (July 2014): 560-590. DOI: 10.1353/tech.2014.0067.

Hanna, Martha. Your Death Would Be Mine: Paul and Marie Pireaud in the Great War. Cambridge: Harvard University Press, 2006.

Herzog, Jonathan P. "America's Spiritual-Industrial Complex and the Policy of Revival in the Early Cold War." Journal of Policy History 22.3 (2010): 337-365. DOI: 10.1017/ S0898030610000138.

Highsmith, Carol M. and Ted Landphair. Forgotten No More: The Korean War Veterans Memorial Story. Washington, D.C.: Chelsea Publishing, Inc., 1995.

Hordes, Martha. "A Story with an Argument: Writing the Transnational Life of a Sea Captain's Wife." Eds. Desley Deacon, Penny Russell and Angela Woollacott. Transnational Lives: Biographies of Global Modernity, 1700-Present. London: Palgrave Macmillan, 2010. 15-26.

Hunter, Kate. "More than an Archive of War: Intimacy and Manliness in the Letters of a Great War Soldier to the Woman He Loved, 1915-1919." Gender E History 25.2 (August 2013): 339-354. DOI: 10.1111/1468-0424.12018.

Hämmerle, Christa. “'You Let a Weeping Woman Call You Home?' Private Correspondences During the First World War in Austria and Germany." Ed. Rebecca Earle. Epistolary Selves: Letters and Letter-Writers, 1600-1945. New York: Routledge, 2016. 152-182.

Kelly, Carol A. "ROA Remembers the Forgotten War: Korea." The Officer 79.5 (July/August 2003). https://search-proquest-com.ez.statsbiblioteket.dk:12048/docview/214110157? OpenUrlRefId=info:xri/sid:summon\&accountid=14468.

Kirby, Dianne. "The Cold War and American Religion." Oxford Research Encyclopedias (2017): 1-36. DOI: 10.1093/acrefore/9780199340378.013.398.

Klein, Robert E. Data on Veterans of the Korean War. Washington, DC: US Department of Veterans Affairs, 2000.

Knopf, Christina M. "Sense-Making and Map-Making: War Letters as Personal Geographies." New American Notes Online (2014). https://nanocrit.com/issues/issue6/sense-makingmap-making-war-letters-personal-geographies.

Kurvet-Käosaar, Leena. "Tracing Emotional Bonds in Family Letters: A Pursuit of an Epistolary Melody." Eds. Kate Douglas and Ashley Barnwell. Research Methodologies for Auto/ Biography Studies. New York: Routledge, 2019. 83-89.

Lepore, Jill. "Historians Who Love Too Much: Reflections on Microhistory and Biography." Journal of American History 88.1 (2001): 129-144. DOI: 10.2307/2674921.

Lindsay, Lisa A. "Biography in African History." History in Africa 44 (2017): 11-26. DOI: 10.1017/hia.2017.1.

Litoff, Judy Barret and David C. Smith. “'Will He Get My Letter?' Popular Portrayals of Mail and Morale During World War II.” Journal of Popular Culture 23.4 (Spring 1990): 21-43. DOI: $10.1111 / \mathrm{j} .0022-3840.1990 .2304 \_21 . x$. 
Lobao, Linda and Katherine Meyer. "The Great Agricultural Transition: Crisis, Change, and Social Consequences of Twentieth Century US Farming." Annual Review of Sociology 27 (2001): 103-124. DOI: 10.1146/annurev.soc.27.1.103.

Magnússon, Sigurður Gylfi. "The Life is Never Over - Biography as a Microhistorical Approach." Eds Hans Renders, Binne de Haan and Jonne Harmsma. The Biographical Turn: Lives in History. New York: Routledge, 2016. 42-52.

May, Elaine Tyler. Homeward Bound: American Families in the Cold War Era. New York: Basic Books, 1988.

McGinn, Andrew. “'Absence makes the heart grow fonder." Jefferson Herald, April 30, 2015. http://jefferson.advantage-preservation.com/Viewer/?k=eason\%20honor\% 20 flight\% 20korea\&i=f\&d=01011917-12312016\&m = between \&fn=jefferson_herald_usa_ iowa_jefferson_20150430_english_5\&df=1\&dt=10.

Millett, Allan R. "The Korean War: 50-Year Critical Historiography." Journal of Strategic Studies 24.1 (2001): 188-224. DOI: 10.1080/01402390108437827.

Net Nebraska. "War Letters." http://netnebraska.org/basic-page/other/war-letters-producers-postscript.

Popkin, Jeremy D. "Life Writing in the Family." a/b: Auto/Biography Studies 25.2 (2010): 172185. DOI: 10.1353 /abs.2010.0038.

Roe, Jill. "Biography Today: A Commentary." Australian Historical Studies 43.1 (2012): 107118. DOI: 10.1080/1031461X.2011.640693.

"Round Table: Self and Subject," Journal of American History 89.1 (2002): 15-53.

Stanley, Liz. "The Epistolarium: On Theorizing Letters and Correspondences." Auto/Biography 12 (2004): 201-235. DOI: 10.1191=0967550704ab014oa.

The Legacy Project. 2008. http://www.warletters.com/.

VandenBerghe, Mary Elizabeth Zill. Korean War Letters: All My Love, Ken. 2013. http:// www.lvandenberghe.net/.

White, Richard. "Here Is the Problem: An Introduction." Journal of American History 89.1 (2002): 17-19. DOI: $10.2307 / 2700777$.

Wirta, Kaarle. "Rediscovering Agency in the Atlantic - A Biographical Approach Linking Entrepreneurial Spirit and Overseas Companies." Eds. Hans Renders, Binne de Haan and Jonne Harmsma. The Biographical Turn: Lives in History. New York: Routledge, 2016. $118-128$.

\section{ABOUT THE AUTHOR}

Elizabeth Bruns is a PhD Fellow with the Department of History at Aarhus University. Her research interests lie broadly in the varying ways and reasons that everyday people in the past have moved and communicated across borders. Her current PhD work investigates education exchanges between the United States and Denmark in the Cold War, in an effort to understand the ways that different types of exchange programs were mobilized to further varying political objectives. She received her BA in History and Political Science from Colorado State University, and her MA in International and Global History from Aarhus University. You can reach her at elbruns@cas.au.dk. 


\section{NOTES}

1 These letters are part of a private collection of the Helen and Curly Eason Family. I have secured permission to use the letters and publish this paper from all relevant family members.

2 Boose Jr., Donald W. and James I. Matray, eds. Ashgate Research Companion to the Korean War. England: Ashgate Publishing Limited, 2014 (1).

3 Clark, Donald N. "Reviewed Work: The Unwanted Symbol: American Foreign Policy, the Cold War, and Korea, 1945-1950 by Charles M. Dobbs." The Public Historian 6:1 (Winter 1984) 82.

4 Highsmith, Carol M. and Ted Landphair. Forgotten No More: The Korean War Veterans Memorial Story. Washington, D.C.: Chelsea Publishing, Inc., 1995 (19).

5 Gartner, Scott Sigmund and Gary M. Segura. "War, Casualties, and Public Opinion." Journal of Conflict Resolution 42, no. 3 (June 1998): 282.

6 Boose and Matray, Ashgate Research, 383.

7 Gartner and Segura, "War, Casualties, and Public Opinion," 282.

8 Boose and Matray, Ashgate Research, 383.

9 McGinn, Andrew. "'Absence makes the heart grow fonder." Jefferson Herald, April 30, 2015, http://jefferson.advantage-preservation.com/Viewer/?k=eason \% 20honor\% 20 flight\%20korea\&i=f\&d=01011917-12312016\&m=between\&fn=jefferson_herald_usa_ iowa_jefferson_20150430_english_5\&df=1\&dt=10.

10 Ibid.

11 Curly Eason, letter to Helen Caulkins Eason, February 7, 1953.

12 Hager, Christopher. I Remain Yours: Common Lives in Civil War Letters. Cambridge Mass. and London: Harvard University Press, 2018 (5).

13 Litoff, Judy Barret and David C. Smith. “'Will He Get My Letter?' Popular Portrayals of Mail and Morale During World War II.” Journal of Popular Culture 23:4 (Spring 1990) 23; Hämmerle, Christa. " 'You let a weeping woman call you home?' Private correspondences during the First World War in Austria and Germany." In Epistolary Selves: Letters and Letter-Writers, 1600-1945, ed. Rebecca Earle. New York: Routledge, 2016 (155-156).

14 Knopf, Christina M. "Sense-Making and Map-Making: War Letters as Personal Geographies." New American Notes Online (2014).

15 Dobson, Miriam. "Letters." In Reading Primary Sources: The Interpretation of Texts from Nineteenth- and Twentieth-Century History, eds. Miriam Dobson and Benjamin Ziemann. New York: Routledge, 2009 (63).

16 For example, see Millett, Allan R. "The Korean War: 50-Year Critical Historiography." Journal of Strategic Studies 24:1 (2001) 188-224.

17 Fehrenbach, T.R. This Kind of War: A Study in Unpreparedness. Bantam, 1963.

18 Kelly, Carol A. "ROA Remembers the forgotten war: Korea." The Officer 79:5 (July/August 2003).

19 Net Nebraska. "War Letters." http://netnebraska.org/basic-page/other/war-lettersproducers-postscript; The Legacy Project. 2008. http://www.warletters.com/; VandenBerghe, Mary Elizabeth Zill. "Korean War Letters: All My Love, Ken.” 2013. http://www. lvandenberghe.net/.

20 Hunter, Kate. "More than an Archive of War: Intimacy and Manliness in the Letters of a Great War Soldier to the Woman He Loved, 1915-1919.” Gender E History 25:2 (August 2013) 339-354; Hager, I Remain.

21 Hämmerle. "Private correspondences." 152-182.

22 Hanna, Martha. Your Death Would Be Mine. Cambridge: Harvard University Press, 2006 (17). 
23 Such as earlier times when letters were indeed meant to be read by a collective, were passed on, etc.

24 Dobson, Miriam. "Letters." 57.

25 Stanley, Liz. "The Epistolarium: On Theorizing Letters and Correspondences." Auto/ Biography 12 (2004) 208.

26 Helen Caulkins. Letter to Curly Eason. April 10, 1951.

27 Helen Caulkins. Letter to Curly Eason. April 12, 1951.

28 Hunter. "More than an Archive." 342; Hanna. Your Death Would Be Mine. 11.

29 Hanna, Martha. Your Death Would Be Mine. 11.

30 In favor of "imaginative readings" see Hordes, Martha. "A Story with an Argument: Writing the Transnational Life of a Sea Captain's Wife." in Transnational Lives: Biographies of Global Modernity, 1700-Present, eds. Desley Deacon, Penny Russell, and Angela Woollacott. London: Palgrave Macmillan, 2010 (15-26).

31 Stanley, Liz. "Epistolarium.” 205.

32 Hager, Christopher. I Remain. 8.

33 Stanley, Liz. "Epistolarium.” 205.

34 Halldórsdóttir, Erla Hulda. "Fragments of Lives - The Use of Private Letters in Historical Research,” Nordic Journal of Women's Studies 15:1 (2007) 43.

35 Ibid., 36.

36 Popkin, Jeremy D. "Life Writing in the Family." a/b: Auto/Biography Studies 25:2 (2010) 174.

37 Barnwell, Ashley. "Working with Family Histories." In Research Methodologies for Auto/Biography Studies eds. Kate Douglas and Ashley Barnwell. New York: Routledge, 2019 (77).

38 Kurvet-Käosaar, Leena. "Tracing Emotional Bonds in Family Letters: A Pursuit of an Epistolary Melody.” In Research Methodologies for Auto/Biography Studies eds. Kate Douglas and Ashley Barnwell. New York: Routledge, 2019 (183).

39 Halldórsdóttir, Erla Hulda. "Baldvin's Tear: The Materiality of the Past." In Making Sense, Crafting History. Practices of Producing Historical Meaning, ed. Izabella Agárdi, Berteke Waaldijk, Carla Salvaterra. Pisa: Plus-Pisa University Press, 2010 (208).

40 Popkin, Jeremy D. "Life Writing in the Family." 174.

41 For perspectives on historical objectivity see: Bevir, Mark. "Objectivity in History." History and Theory 33:3 (Oct 1994) 328-344. For perspectives on self and subject see: "Round Table: Self and Subject.” Journal of American History 89:1 (June 2002) 15-53. See also Caine, Barbara. Biography and History. Hampshire: Palgrave Macmillan, 2010 (66-84).

42 Demos, John. "Using Self, Using History..." Journal of American History 89:1 (June 2002) 37, 42.

43 Popkin, Jeremy D. "Life Writing in the Family." 174.

44 Helen Caulkins. Letter to Curly Eason. April 19, 1951. Note: Helen and Curly employ colloquial language in their letters. I will refrain from correcting words that are abbreviated in this style, for example: "nite" or "lovin.'“

45 Halldórsdóttir, Erla Hulda. "Baldvin's Tear." 213; Lepore, Jill. "Historians Who Love Too Much: Reflections on Microhistory and Biography." Journal of American History 88:1 (2001) 129.

46 Halldórsdóttir, Erla Hulda. "Baldvin's Tear." 207-208.

47 White, Richard. "Here's the Problem: An Introduction." Journal of American History 89:1 (2002) 18.

48 Halldórsdóttir, Erla Hulda. "Baldvin's Tear."; Halldórsdóttir, Erla Hulda. "Fragments."

49 Halldórsdóttir, Erla Hulda "Baldvin's Tear." 215-216.

50 Caine, Barbara. Biography and History. 113.

51 Lindsay, Lisa A. "Biography in African History." History in Africa 44 (2017) 15.

52 Ibid. 
53 Caine, Barbara. Biography and History. 2-3; Wirta, Kaarle. "Rediscovering Agency in the Atlantic - A biographical approach linking entrepreneurial spirit and overseas companies." In The Biographical Turn: Lives in History, eds. Hans Renders, Binne de Haan, and Jonne Harmsma. New York: Routledge, 2016 (118-128).

54 Magnússon, Sigurður Gylfi. "The Life is Never Over - Biography as a microhistorical approach.” In The Biographical Turn: Lives in History, eds. Hans Renders, Binne de Haan, and Jonne Harmsma. New York: Routledge, 2016 (42-52).

55 Lepore, Jill. "Historians Who Love Too Much.” 142.

56 Bayly, C. A. et al. "AHR Conversation on Transnat'l History." The American Historical Review 11:5 (2006) 1444.

57 Fleischmann, Ellen. "'I only wish I had a home on this globe': Transnational Biography and Dr. Mary Eddy.” Journal of Women's History 21:3 (2009) 113.

58 Ibid.

59 Klein, Robert E. "Data on Veterans of the Korean War." US Department of Veterans Affairs (June 2000) 1.

60 The historical perspective on the nature of American military outposts is eloquently discussed by Blower, Brooke L. "Nation of Outposts: Forts, Factories, Bases, and the Making of American Military Power.” Diplomatic History 41:3 (2017) 439-459.

61 Helen Caulkins. Letter to Curly Eason. April 8, 1951.

62 Helen Caulkins. Letter to Curly Eason. July 20, 1951.

63 Helen Caulkins. Letter to Curly Eason. June 16, 1951.

64 May, Elaine Tyler. Homeward Bound: American Families in the Cold War Era. New York: Basic Books, 1988 (1).

65 Ibid., 3.

66 Ibid., 20.

67 Ibid., 59.

68 Helen Caulkins. Letter to Curly Eason. June 4, 1951.

69 Ibid., 60.

70 Helen Caulkins. Letter to Curly Eason. April 19, 1951.

71 Helen Caulkins. Letter to Curly Eason. April 14, 1951; June 27, 1951; July 4, 1951.

72 Helen Caulkins Eason. Letter to Curly Eason. September 17, 1951; Curly Eason. Letter to Helen Caulkins Eason. January 2, 1953; January 4, 1953.

73 Cherlin, Andrew J. "American Marriage in the Early Twenty-First Century." The Future of Children 15:2 (Autumn 2005) 34, 40.

74 Helen Caulkins. Letter to Curly Eason. June 12, 1951.

75 Ibid.

76 Helen Caulkins. Letter to Curly Eason. June 14, 1951.

77 Helen Caulkins. Letter to Curly Eason. July 19, 1951.

78 Dobson, Miriam. "Letters." 63.

79 Hager, Christopher. I Remain. 6.

80 Ibid., 10.

81 Helen Caulkins Eason. Letter to Curly Eason. October 31, 1951.

82 Hunter, Kate. "More than an Archive." 344.

83 Ibid.

84 Kurvet-Käosaar, Leena. "Tracing Emotional Bonds.” 84.

85 Helen Caulkins. Letter to Curly Eason. July 1, 1951.

86 Helen Caulkins. Letter to Curly Eason. July 4, 1951.

87 Hunter, Kate. "More than an Archive." 347.

88 Helen Caulkins Eason. Letter to Curly Eason. September 17, 1951.

89 Curly Eason. Letter to Helen Caulkins Eason. December 2, 1951.

90 Helen Caulkins Eason. Letter to Curly Eason. October 27, 1951. 
91 Curly Eason. Letter to Helen Caulkins Eason. October 27, 1951.

92 Helen Caulkins Eason. Letter to Curly Eason. October 28, 1951.

93 Helen Caulkins Eason. Letter to Curly Eason. November 12, 1951.

94 Curly Eason. Letter to Helen Caulkins Eason. November 10, 1951.

95 Curly Eason. Letter to Helen Caulkins Eason. November 18, 1951.

96 Ibid. See Figure 3.

97 Canipe, Lee. "Under-God and Anti-Communist: How the Pledge of Allegiance Got Religion in Cold War America." Journal of Church and State 45:2 (Spring 2003) 312; Kirby, Dianne. "The Cold War and American Religion." Oxford Research Encyclopedias (May 2017) 1.

98 Herzog, Jonathan P. "America's Spiritual-Industrial Complex and the Policy of Revival in the Early Cold War." Journal of Policy History 22:3 (2010) 338.

99 Ibid.

100 Kirby, Dianne. "The Cold War." 8.

101 Curly Eason. Letter to Helen Caulkins Eason. January 2, 1953.

102 Curly Eason. Letter to Helen Caulkins Eason. January 8, 1953.

103 McGinn, Andrew. "Absence."

104 Helen Caulkins. Letter to Curly Eason. July 15, 1951.

105 Curly Eason. Letter to Helen Caulkins Eason. January 2, 1953.

106 A topic also explored by Hanna, Martha. Your Death Would Be Mine. 18.

107 Helen Caulkins. Letter to Curly Eason. April 5, 1951.

108 Helen Caulkins. Letter to Curly Eason. July 14, 1951.

109 Curly Eason. Letter to Helen Caulkins Eason. November 20, 1951.

110 Curly Eason. Letter to Helen Caulkins Eason. January 5, 1953.

111 Curly Eason. Letter to Helen Caulkins Eason. January 16, 1953. Note: The Timber Lodge place was one part of the Eason family property in Iowa.

112 Curly Eason. Letter to Helen Caulkins Eason. February 3, 1953.

113 Curly Eason. Letter to Helen Caulkins Eason. February 6, 1953.

114 Lobao, Linda and Katherine Meyer. "The Great Agricultural Transition: Crisis, Change, and Social Consequences of Twentieth Century US Farming." Annual Review of Sociology (2001) 103-124.

115 Dimitri, Carolyn, Anne Effland, and Nielson Conklin. "The $20^{\text {th }}$ Century Transformation of US Agriculture and Farm Policy." United States Department of Agriculture, Economic Research Service, Economic Information Bulletin No. 3 (June 2005) 5.

116 Hamilton, Shane. "Agribusiness, the Family Farm, and The Politics of Technological Determinism in the Post-World War II United States." Technology and Culture 55:3 (July 2014) 561.

117 Roe, Jill. "Biography Today: A Commentary." Australian Historical Studies 43:1 (2012) 118.

118 Omohundo Institute of Early American History and Culture, "Call for Papers for a Conference on Microhistory: Advantages and Limitations for the Study of Early American History," 1998, as quoted in Lepore, Jill. "Historians Who Love Too Much.” 131. 